\title{
Effect of durophagy on drilling predation: a case study of Cenozoic molluscs from North America
}

\author{
Devapriya Chattopadhyay ${ }^{\mathrm{a} \dagger} *$ and Tomasz K. Baumiller ${ }^{\mathrm{b}}$ \\ ${ }^{a}$ Department of Geosciences, University of West Georgia, 1601 Maple Street, Carrollton, GA 30118, USA; ${ }^{b}$ Museum of Paleontology, \\ University of Michigan, Ann Arbor, MI 48109, USA
}

(Received 20 September 2009; final version received 31 January 2010)

\begin{abstract}
Drilling predation represents one of the most widely studied biotic interactions preserved in the fossil record, and complete and incomplete drill holes have been commonly used to explore spatial and temporal patterns of this phenomenon. While such patterns are generally viewed solely in terms of the interactions between predator and prey, they might also be affected by extrinsic ecological factors. Recent experiments have demonstrated that in the presence of a secondary predator (crab), the incomplete drilling frequency increases indicating increasing abandonment of the prey, and drilling frequency decreases implying a decrease in successful attacks. Here, we tested whether the effect of secondary predators on drilling frequencies can be detected in the fossil record. Using fossil molluscs from six Plio-Pleistocene localities, we found that repair scar frequencies, a proxy for activity of durophagous predators, correlate directly with incomplete drill hole frequencies and inversely with complete drill hole frequencies. These results suggest that the activity and success of drilling predators is influenced not just by the prey, but also by secondary predators.
\end{abstract}

Keywords: drilling predation; durophagy; molluscs

\section{Introduction}

Predator-prey interactions have been a topic of interest to paleontologists due to their ecological importance but especially because of their potential evolutionary implications. For example, predation has been claimed to influence rates of evolution (Stanley 1974, 1979), considered as a causal factor in the rise of biomineralisation (Stanley 1976; Conway Morris and Bengston 1998) and in diversification and extinction (Vermeij 1987; Jablonski and Sepkoski 1996). Also, it has been suggested that predator-prey interactions drive long-term morphological and behavioural trends in various clades (Signor and Brett 1984; Vermeij 1987).

One of the main problems in testing evolutionary hypotheses that emphasise predation, such as the ones listed above, is that direct evidence of most predatorprey interactions is rare or absent in the fossil record (Leighton 2002). While the absence of direct evidence is not fatal to such hypotheses, it does make them difficult to test; therefore, identifying predator-prey systems for which such evidence is available is highly desirable. Predation by drilling gastropods on their shelled, typically molluscan, prey represents one such system. Drilling gastropods often leave distinct markings on their shelled prey making it possible not only to identify the victims but also the predators and, importantly, to obtain quantitative estimates for a variety of relevant metrics. Such metrics include the frequency of drill holes, used to estimate predation intensity (Taylor 1970; Stanton and Nelson 1980; Vermeij et al. 1980; Vermeij and Dudley 1982; Kabat and Kohn 1986), frequency of incomplete drill holes, used as a measure of failed predation events (but see Kowalewski 2004) and thus prey-effectiveness (Kelley and Hansen 2001), position of drill holes and distribution of sizes of prey, used to evaluate predatory strategies, and taxonomic distribution of drill holes, used to explore selectivity.

The drilling predator-prey system, because it is common in modern marine environments, also has the advantage of providing researchers an opportunity for studying its details through neontological experiments. As a consequence, drilling predator-prey systems have drawn a lot of attention over the past couple of decades (summarised by Kowalewski et al. 1998). Some of these studies have used drilling frequencies to test different hypotheses about prey selectivity (Ausich and Gurrola 1979; Vermeij and Dudley 1982; Hoffman and Martinell 1984; Colbath 1985; Tull and Bohning-Gaese 1993; Leighton 2003), predator behaviour (Berg and Nishenko 1975; Zlotnik 2001; Deline et al. 2003) while others have explored broad-scale temporal patterns in predation intensity based on drilling frequency data (Vermeij 1987;

*Corresponding author. Email: dchattop@westga.edu

Current address: IISER-Kolkata, Mohanpur Campus, Nadia, WB-741252, India. 
Kelley and Hansen 1993; Kowalewski et al. 1998; Huntley and Kowalewski 2007).

Another type of predator-prey interaction that offers similar advantages is durophagy, since shell-crushing predators sometimes leave diagnostic marks on their prey. Although two categories of pre-ingestive breakage have been recognised, namely lethal and sublethal (repaired) damage, lethal fractures are often less diagnostic of the causal agent and are often indistinguishable from abiotic (taphonomic) agents of shell degradation; sublethal damage, on the other hand, is relatively easy to identify. Consequently, repair scar frequencies are more commonly used in studies of durophagous predation. For example, they have been used to evaluate the importance of predation as a selective agent (Andrews 1935; Rand 1954; Vermeij et al. 1981; Vermeij 1982; Allmon et al. 1990; Huntley and Kowalewski 2007). Although it must be recognised that repair scars represent failed attacks and are thus analogous to incomplete rather than complete drill holes (Vermeij 1987; Allmon et al. 1990; Leighton 2001, 2002; Harper 2006), they can be used as proxy for predatory activity. This is supported by a recent study with live blue crabs and periwinkles by Moody and Aronson (2007) which demonstrated that the occurrence of sublethal shell repair in Littorina was positively correlated with the frequency of predatory attacks and the abundance of crabs.

In many paleontological studies of predator-prey interactions, the system has been treated from a two-taxon perspective, that of the predator and its prey; interactions with other predators have generally not been considered. However, among ecologists the past few decades have seen much discussion devoted to the interaction between different predator groups and the resulting 'emergent effects' (Sih et al. 1985, 1998; Lima and Dill 1990). Given that natural communities typically have multiple predators feeding on many prey, understanding emergent multiple predator effects (MPEs) is a critical issue for community ecology (Wilbur and Fauth 1990; Wooton 1994). Studies suggest two main types of emergent effects: (1) risk reduction caused by predator-predator interactions and (2) risk enhancement caused by conflicting prey responses to multiple predators. However, very few studies have been designed to test for the evolutionary consequences of predation in the context of MPEs (Dietl and Kelley 2004). For studies of drilling predation, which are often used in testing temporal trends, MPEs may be especially important as they have the potential for affecting drilling frequencies and thus affecting conclusions based on drilling frequency data.

\section{Influence of durophages on drilling predators}

A number of recent studies have looked into the behavioural response of prey in the presence of a predator. Some of these studies have emphasised trait-mediated indirect interactions (TMIIs; Abrams et al. 1996). For example, water-borne cues ('risk cues') released by predators can cause changes in prey species behaviour, such as feeding rates, thereby altering the impact of the prey species on their resources. Thus, TMIIs represent the non-lethal effects of predators that contrast with the more traditional emphasis on lethal indirect effects.

Predator-induced changes in prey behaviour that reduce risk of predation, such as alterations in feeding rate or habitat use (Dill 1987; Lima 1988a, 1988b; Werner and Anholt 1993; Turner 1996; Turner et al. 1999) also may modify the prey's impact on its resources (Turner and Mittlebach 1990; Turner 1997; Turner et al. 2000). For instance, snails exposed to predatory crabs exhibit reduced activity, reduced feeding levels and increased use of inconspicuous or 'refuge' habitats (Palmer 1990; Marko and Palmer 1991). Palmer (1990) noted that Nucella lapillus feeding in the presence of green crab preferred to consume barnacles located on the underside rather than on top of stones placed within experimental chambers. In contrast, $N$. lapillus feeding in the absence of these cues showed little discrimination with respect to the position of their barnacle prey and consumed significantly more barnacles.

Trussell et al. (2003) examined whether risk cues released by a secondary predator (blue crab) influenced the behaviour of its snail prey and whether this was reflected in the abundance of the snail's two dominant prey species, barnacles and fucoid algae. They found that the presence of crab risk cues had strong cascading indirect effects on the abundance of barnacles and fucoid algae. Gastropods exposed to risk cues consumed significantly fewer barnacles and algae compared to conspecifics feeding in the absence of risk cues. The snails also exhibited more refuge-seeking behaviour and grew less in the presence of risk cues.

In another recent experimental study (Chattopadhyay and Baumiller 2007), the presence of a secondary predator (a crab) was found to have a significant effect on the behaviour of a drilling predator (muricid gastropod) preying upon mussels: in the presence of the crab, the driller's success rate decreased resulting in a decrease in overall drilling frequency and an increase in incomplete drilling frequency (increase in prey-effectiveness).

The above neontological studies suggest that the mere presence of a secondary predator may have a significant effect on the predator and this is likely to have been the case in natural systems of the past. To test this in the fossil record requires being able to measure the activity of secondary predators as well as those of drilling predators. In this study, using repair scars as a proxy for the activities of secondary predators, we test the affected behaviour of drilling predators, as measured by the frequencies of complete and incomplete drill holes. 
Table 1. List of bivalve and gastropod species from six localities used in this study.

\begin{tabular}{|c|c|c|c|c|c|}
\hline Locality & Taxa & Total & Drilled & $\begin{array}{l}\text { Incompletely } \\
\text { drilled }\end{array}$ & Repaired \\
\hline \multirow[t]{18}{*}{ Neuse River, NC (James City Fm.) } & Tellina alternata & 435 & 13 & 26 & 76 \\
\hline & Spisula solidissima & 60 & 7 & 7 & 7 \\
\hline & Donax sp. & 696 & 33 & 27 & 33 \\
\hline & Nucula proxima & 49 & 6 & 2 & 2 \\
\hline & Corbula contracta & 34 & 2 & 4 & 3 \\
\hline & Trachycardium sp. & 196 & 19 & 11 & 11 \\
\hline & Mulinia lateralis & 200 & 9 & 13 & 16 \\
\hline & Noetia $s p$ & 53 & 4 & 7 & 2 \\
\hline & Mulinia sp. & 169 & 7 & 2 & 11 \\
\hline & Chione sp. & 49 & 5 & 2 & 3 \\
\hline & Tellina sp. & 36 & 1 & 0 & 3 \\
\hline & Anadara transversa & 169 & 10 & 4 & 14 \\
\hline & Crepidula plana & 79 & 14 & 6 & 8 \\
\hline & Cancellaria reticulata & 129 & 24 & 9 & 8 \\
\hline & Terebra dislocata & 26 & 9 & 3 & 0 \\
\hline & Oliva sayana & 18 & 1 & 0 & 1 \\
\hline & N. duplicata & 16 & 4 & 0 & 2 \\
\hline & Marginella sp. & 18 & 1 & 0 & 1 \\
\hline \multirow[t]{5}{*}{ Punta Gorda, FL (Caloosahatchee Fm.) } & Chione elevata & 449 & 301 & 18 & 10 \\
\hline & Tellina alternata & 45 & 5 & 2 & 0 \\
\hline & Anadara transversa & 1826 & 118 & 37 & 11 \\
\hline & Eucrassatella speciosa & 67 & 6 & 3 & 2 \\
\hline & N. duplicata & 30 & 5 & 0 & 11 \\
\hline \multirow[t]{7}{*}{ Miami Canal, FL (Caloosahatchee Fm.) } & Chione elevata & 4119 & 550 & 113 & 15 \\
\hline & Mulinia lateralis & 45 & 2 & 0 & 1 \\
\hline & Arca sp. & 31 & 1 & 2 & 0 \\
\hline & Natica plicatella & 94 & 23 & 5 & 2 \\
\hline & Marginella sp. & 324 & 161 & 14 & 6 \\
\hline & N. duplicata & 130 & 26 & 6 & 15 \\
\hline & Strombus alatus & 51 & 2 & 2 & 7 \\
\hline \multirow[t]{6}{*}{ McQueen's pit, FL (Caloosahatchee Fm.) } & Anadara transversa & 136 & 14 & 6 & 7 \\
\hline & Chione elevata & 232 & 72 & 6 & 3 \\
\hline & Tellina sp. & 114 & 1 & 0 & 5 \\
\hline & Eucrassatella speciosa & 113 & 10 & 0 & 1 \\
\hline & N. duplicata & 8 & 0 & 1 & 3 \\
\hline & Cerithium atratum & 54 & 2 & 0 & 2 \\
\hline \multirow[t]{17}{*}{ Deadman's Island, CA (Lower San Pedro Fm.) } & Transennella tantilla & 1044 & 104 & 6 & 16 \\
\hline & Phacoides californicus & 141 & 23 & 0 & 5 \\
\hline & Phacoides sp. & 184 & 11 & 4 & 12 \\
\hline & Protothaca staminea & 325 & 74 & 1 & 4 \\
\hline & Amphissa versicolor & 1271 & 84 & 0 & 34 \\
\hline & Alectrion perpinguis & 417 & 41 & 0 & 11 \\
\hline & Alectrion mendicus & 139 & 16 & 0 & 7 \\
\hline & Alectrion? mendicus & 265 & 19 & 0 & 28 \\
\hline & Tricolia sp. & 551 & 12 & 1 & 22 \\
\hline & Alia sp. & 718 & 14 & 9 & 162 \\
\hline & Alectrion cooperi & 62 & 2 & 0 & 15 \\
\hline & Lacuna compacta & 129 & 2 & 0 & 13 \\
\hline & Alia carinata & 110 & 1 & 0 & 24 \\
\hline & Alectrion? cooperi & 683 & 69 & 1 & 39 \\
\hline & Mitrella gausapata & 425 & 10 & 4 & 84 \\
\hline & Mitrella sp. & 627 & 29 & 12 & 163 \\
\hline & Alectrion sp. & 1041 & 63 & 0 & 90 \\
\hline \multirow[t]{7}{*}{ Chiquita, FL (Caloosahatchee Fm.) } & Ostrea virginica & 31 & 2 & 0 & 15 \\
\hline & Tellina alternata & 359 & 24 & 8 & 5 \\
\hline & Brachidontes sp. & 70 & 1 & 2 & 29 \\
\hline & Chione elevata & 313 & 7 & 6 & 47 \\
\hline & Marginella sp. & 12 & 1 & 0 & 5 \\
\hline & Cerithium atratum & 43 & 0 & 2 & 15 \\
\hline & N. duplicata & 66 & 3 & 3 & 10 \\
\hline
\end{tabular}




\section{Materials and methods}

The Plio-Pleistocene geological record of North America contains numerous localities in which drilling snails and their molluscan prey (both bivalves and gastropods) are common. Specimens from these localities show evidence of frequent, though variable, predatory activities of these snails as evidenced by drill holes. While fossils of durophagous predators are much less common, their activities are preserved in the form of repair scars. Using bulk samples collected from six Plio-Pleistocene localities in Florida, North Carolina and California and housed in the Museum of Paleontology, University of Michigan, we examined 18,963 fossil specimens of 16 bivalve genera and 14 gastropod genera for evidence of durophagous and drilling predation (Table 1). The number of specimens from each locality ranged from 300 to 7000 and from 3 to 6 genera. Specimens were sorted based on the presence of predation marks such as

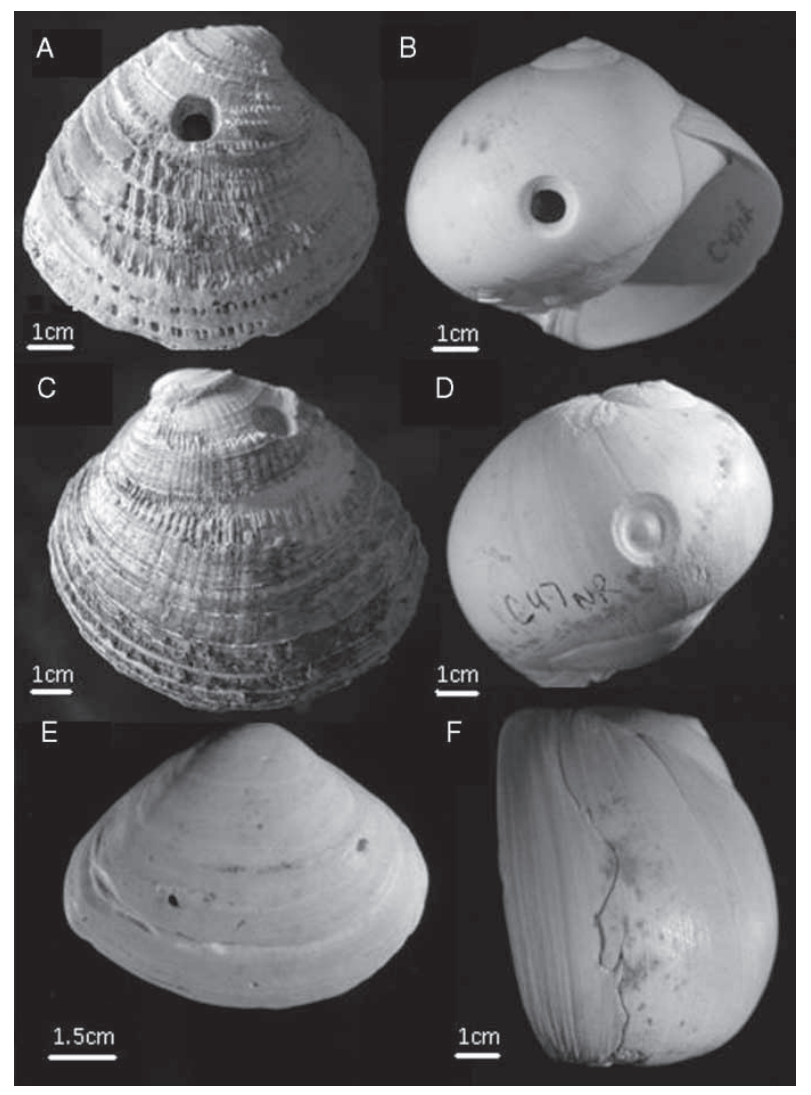

Figure 1. (A) Neverita duplicata (loc. Miami Canal, FL) with a complete naticid drill hole. (B) Chione elevata (loc. Miami Canal, FL) with a complete naticid drill hole. (C) Chione elevata (loc. Punta Gorda, FL) with an incomplete naticid drill hole. (D) Neverita duplicata (loc. Miami Canal, FL) with an incomplete naticid drill hole. (E) Spisula solidissima (loc. Neuse River, NC) with repair scar parallel to the growth lines. (F) Neverita duplicata (loc. Miami Canal, FL) with repair scar near the aperture. complete drill holes, incomplete drill holes and repair scars (Figure 1(A)-(F)). Drill hole morphology was categorised either as countersunk or cylindrical as it provides some clues about the identity of the predator (Kelley and Hansen 2003). The specimens were manually counted after sorting.

Three parameters were calculated: repair scar frequency, drilling frequency and incomplete drill hole frequency. For gastropods, the drilling frequency was calculated by dividing the number of complete drill holes by the total number of individuals. In calculating repair scar frequency, we adopted the 'scars per shell' method (Vermeij et al. 1981; Dietl and Alexander 1998; Dietl et al. 2000; Alexander and Dietl 2001) where the total number of repair scars was divided by the total number of individuals in a sample. Since all of our bivalve specimens were disarticulated, we used the formulae recommended by Kowalewski (2002) dividing the number of individuals with predation marks by half the total number of valves. The formula for incomplete drill hole frequency is the same for bivalves and gastropods since it is not affected by disarticulation and it was calculated by dividing the number of incomplete drill holes by the sum of complete and incomplete drill holes (it is the same formulae used to calculate prey-effectiveness defined by Vermeij 1987). Average drilling frequency, repair scar frequency and incomplete drilling frequency for each locality were also calculated for bivalves and gastropods separately.

In order to obtain average length and thickness, we also measured the length and thickness of 25 random individuals from each species using digital calipers (to the nearest $0.01 \mathrm{~mm}$ ). We measured thickness at a fixed point in the midsection of the bivalve shells. For the gastropods, thickness was measured near the aperture. Average thickness of the shell for each locality was calculated separately for bivalves and gastropods.

\section{Data analysis}

We used various techniques of data analysis in this study because of some unique features of our data. Although our sample size is quite large ( $\sim 19,000$ specimens $)$, these are distributed only among six localities. Also, at each locality, the number of specimens representing each species differs as does the attack frequency. To test the hypotheses for the six localities, we first ignored taxonomic influence on the patterns and simply calculated the 'overall average frequency' (the total number of predation traces compared to total number of specimens), for each locality. However, it is unlikely that taxonomy is irrelevant since it has been widely documented that predators can be highly selective. To account for the impact of taxonomy on the patterns, the average predation trace frequency was calculated for each species, summed 
up and divided by the number of species, resulting in a 'species average predation trace frequency' for each locality.

To test the significance for the second method, a bootstrap computer simulation was developed to test the null hypothesis of no correlation between repair scar-drilling frequency and repair scar-incomplete-drillhole frequency (Ho: Spearman $\rho_{\text {repair scar-drilling }}=$ Spearman $\rho_{\text {repair scar-incomplete drilling }}=0$ ). Spearman $\rho$ was used to measure the correlation between any two sets of variables. The simulation allowed us to ask how many times a trend comparable to the observed one could be produced by chance. We generated drilling frequency data for each locality by randomly choosing drilling frequencies from the list of observed drilling frequencies.

The same procedure was used to generate repair scar frequencies. Once simulated frequencies had been generated for all localities, the average repair scar frequency and drilling frequency could be calculated for each locality. Spearman $\rho$ was used as a measure of correlation between average repair scar frequencies and drilling frequencies. After each iteration, Spearman $\rho$ was calculated by correlating the six data points on that run. By running the simulation 1000 times, a frequency distribution of the $\rho$ s was obtained and this was compared to the observed $\rho$. The same approach was used to explore the relationship between repair scar frequency and incomplete drilling frequency.

\section{Results}

Examining the 'overall average frequency' for drilling, repair scars and incomplete drill holes reveal several patterns consistent with the hypotheses. Regression

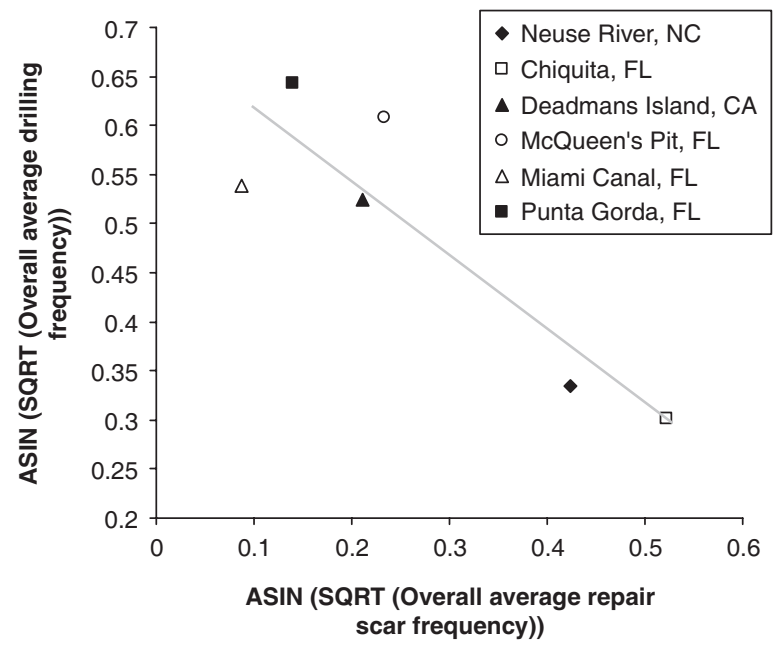

Figure 2. Plot showing the relationship between transformed overall average repair scar frequencies and drilling frequencies for bivalves specimens for six localities.

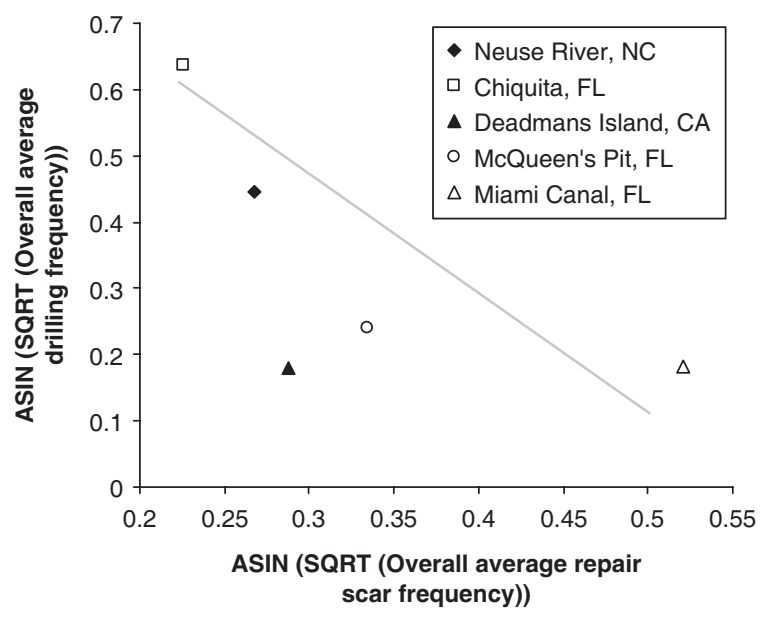

Figure 3. Plot showing the relationship between transformed overall average repair scar frequencies and drilling frequencies for gastropods specimens for five localities. Locality 6 (Punta Gorda) was not included since it is only represented by one species.

between repair scar frequencies and drilling frequencies using transformed ASIN[SQRT(Proportion)] \} shows that there is a negative relationship for both bivalves and gastropods (Figures 2 and 3). Although the relationship is significant for bivalves $(p=0.01)$, it is only marginally significant for gastropods $(p=0.1)$. Also, a positive relationship characterises repair scar frequencies and incomplete drilling frequencies for both bivalves and gastropods (Figures 4 and 5). However, this relationship is marginally significant $(p=0.1)$.

Similar patterns emerge when 'species average frequencies' are examined. A significant negative correlation exists between species average repair scar

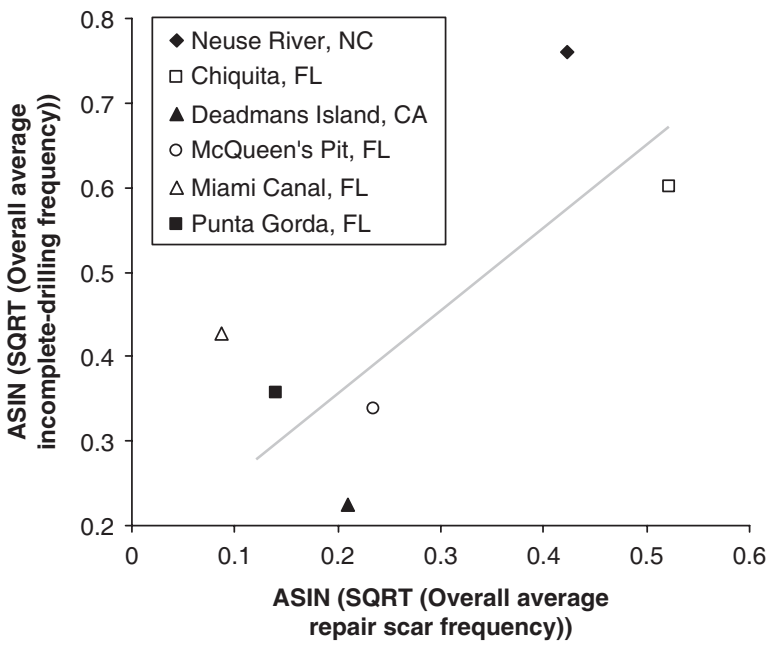

Figure 4. Plot showing the relationship between transformed overall average repair scar frequencies and incomplete drilling frequencies for bivalves specimens for six localities. 


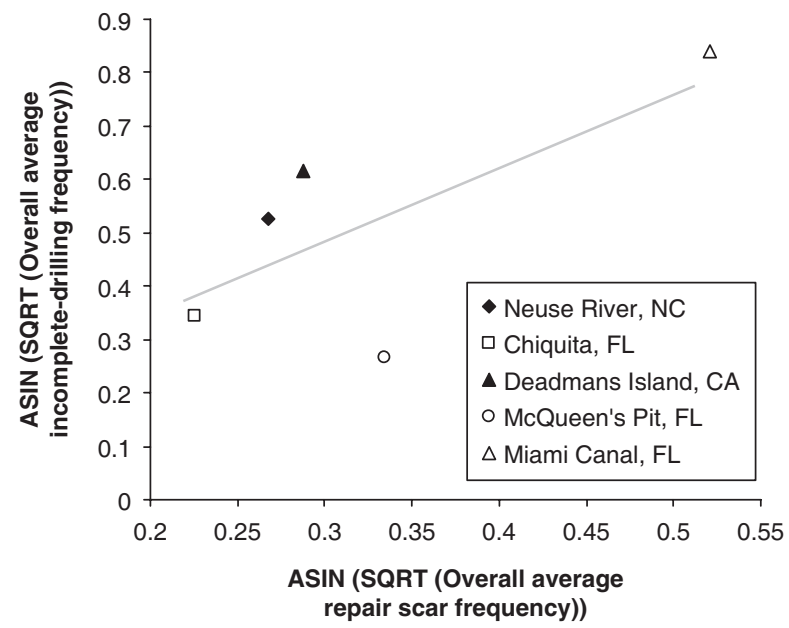

Figure 5. Plot showing the relationship between transformed overall average repair scar frequencies and incomplete drilling frequencies for gastropods specimens for five localities. Locality 6 (Punta Gorda) was not included since it is only represented by one species.

(a)
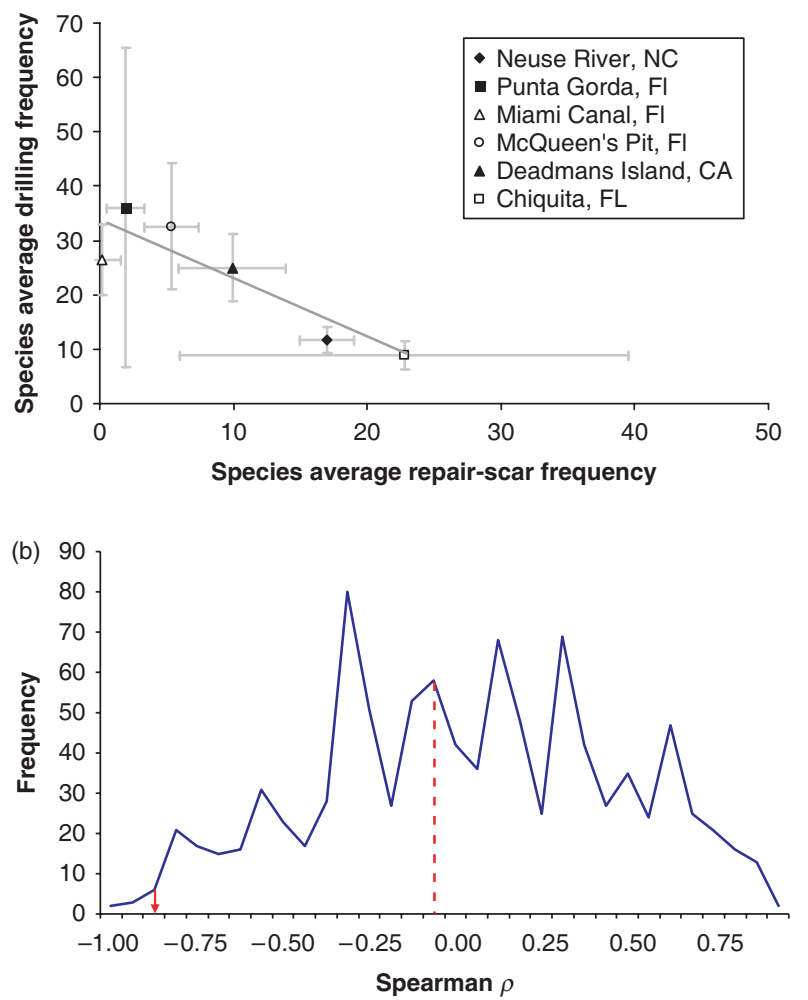

Figure 6. (a) Plot showing the relationship between species average repair scar frequencies and drilling frequencies for bivalves specimens for six localities. The error bars indicate standard error for frequencies of repair scar and drilling. (b) Results of simulation run for estimating the significance of the relationship between average repair scar frequency and drilling frequency for bivalves. The dashed line represents median of the simulation whereas the solid arrow represents the observed value of Spearman $\rho$ in our study. (a)
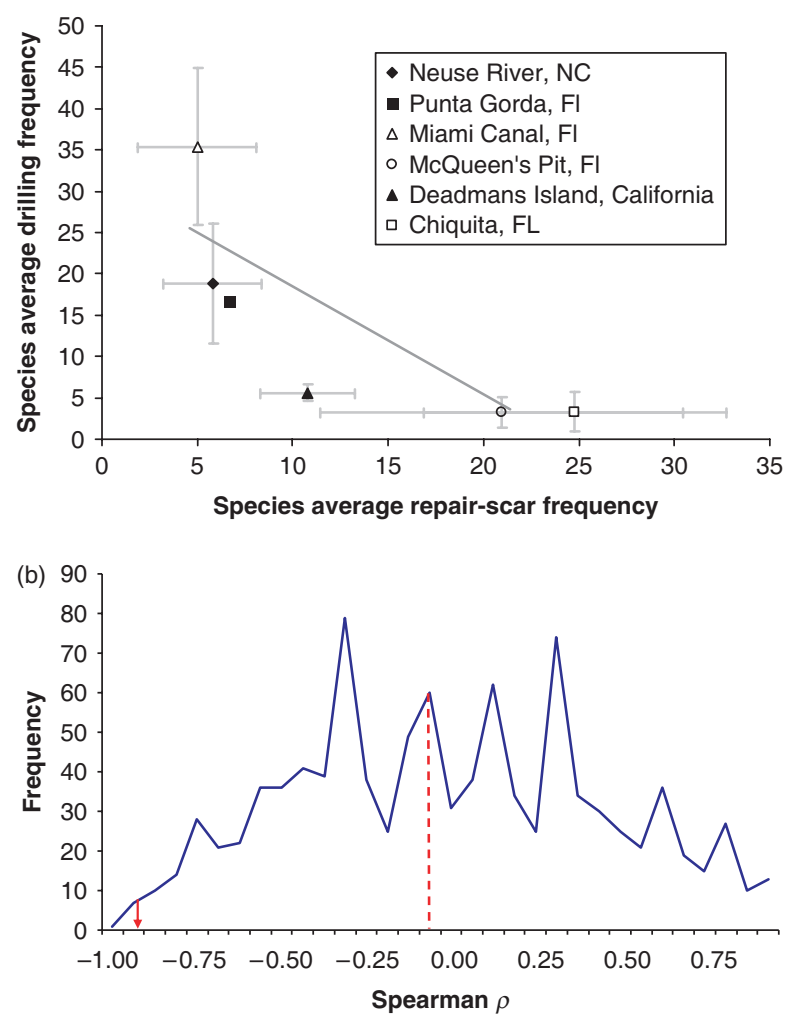

Figure 7. (a) Plot showing the relationship between species average repair scar frequencies and drilling frequencies for gastropods specimens for six localities. The error bars indicate standard error for frequencies of repair scar and drilling. Note there is no error bars associated with the point representing Punta Gorda, FL since we had only one gastropod taxon from there. (b) Results of simulation run for estimating the significance of the relationship between average repair scar frequency and drilling frequency for gastropods. The dashed line represents median of the simulation whereas the solid arrow represents the observed value of Spearman $\rho$ in our study.

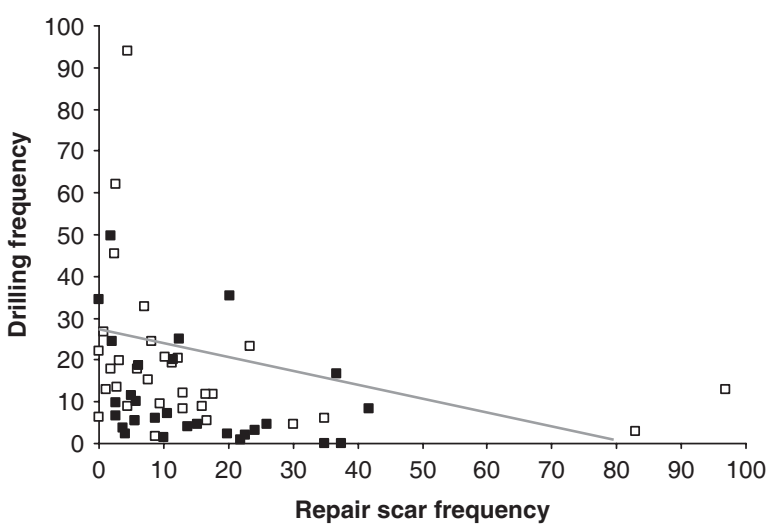

Figure 8. Plot showing the relationship between repair scar frequencies and drilling frequencies for all the groups. Bivalves are represented by open squares and gastropods by solid squares. 
Table 2. Contingency table for the $\chi^{2}$-test performed to evaluate the correlation between drilling frequency and repair scar frequency for both bivalves and gastropods. Repair scars frequency categories are ' 0 to less than 8 ' and ' 8 and higher'. Drilling frequency categories are ' 0 to less than 10 ' and ' 10 and higher'.

\begin{tabular}{llr}
\hline & \multicolumn{2}{c}{ Drilling frequency } \\
\hline Repair scar frequency & 10 & 20 \\
& 18 & 13 \\
\hline
\end{tabular}

and species average drilling frequencies for both bivalves (Spearman $\rho=-0.81, p=0.03$ ) and gastropods (Spear$\operatorname{man} \rho=-0.94, p \leq 0.01$; Figures 6a,b and 7a,b). Levels of significance were obtained using a bootstrap technique (discussed above). When bivalves and gastropods of all localities are considered together, there is a significant negative correlation between species average drilling and repair scar frequencies ( $\chi^{2}$-test, $p=0.02$; Figure 8 and Table 2).

A significant positive correlation exists between species average repair scar and incomplete drill hole
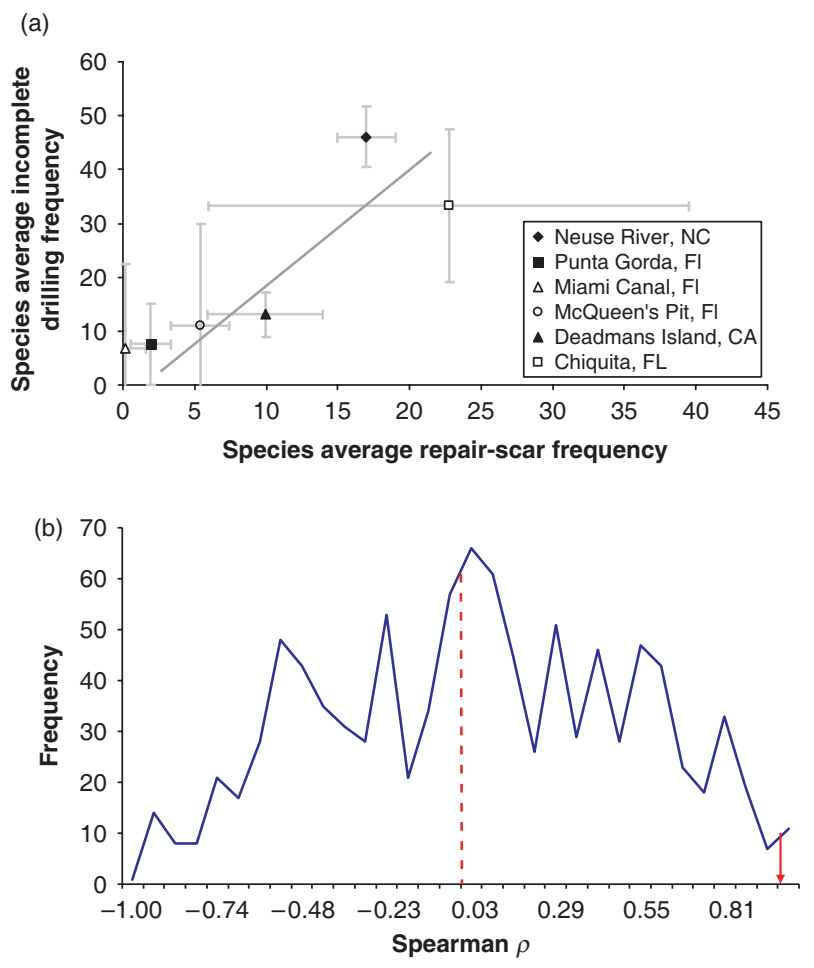

Figure 9. (a) Plot showing the relationship between species average repair scar frequency and incomplete drilling frequency for bivalves specimens for six localities. The error bars indicate standard error for frequencies of repair scar and incomplete drilling. (b) Results of simulation run for estimating the significance of the relationship between average repair scar frequency and incomplete drilling for bivalves. The dashed line represents median of the simulation whereas the solid arrow represents the observed value of Spearman $\rho$ in our study.
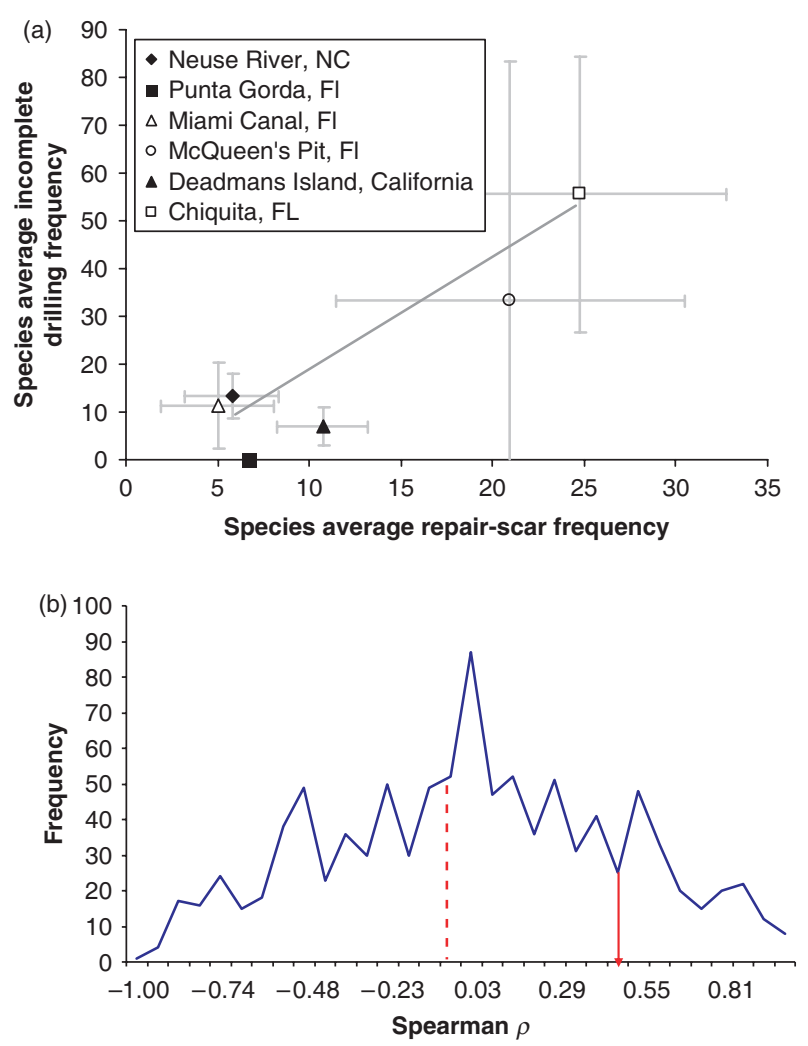

Figure 10. (a) Plot showing the relationship between species average repair scar frequency and incomplete drilling frequency for gastropods specimens for six localities. The error bars indicate standard error for frequencies of repair scar and incomplete drilling. Note there is no error bars associated with the point representing Punta Gorda, FL since we had only one gastropod taxon from there. (b) Results of simulation run for estimating the significance of the relationship between average repair scar frequency and incomplete drilling frequency for gastropods. The dashed line represents median of the simulation whereas the solid arrow represents the observed value of Spearman $\rho$ in our study.

frequencies for bivalves (Spearman $\rho=0.91, p=0.02$; Figure 9a,b). The same holds true for gastropods and it is statistically significant (Spearman $\rho=0.54, p=0.05$; Figure 10a,b). When bivalves and gastropods of all localities are considered together, there is a significant positive correlation between species average incomplete drilling and repair scar frequencies $\left(\chi^{2}\right.$-test, $p=0.05$; Figure 11 and Table 3).

\section{Discussion}

In this study, we asked whether frequencies of complete and incomplete drill holes might be correlated with frequencies of repair scars, testing the hypothesis that the behaviour of drilling predators is significantly impacted by the activities of secondary, durophagous predators. The results are consistent with this prediction: the frequency of 


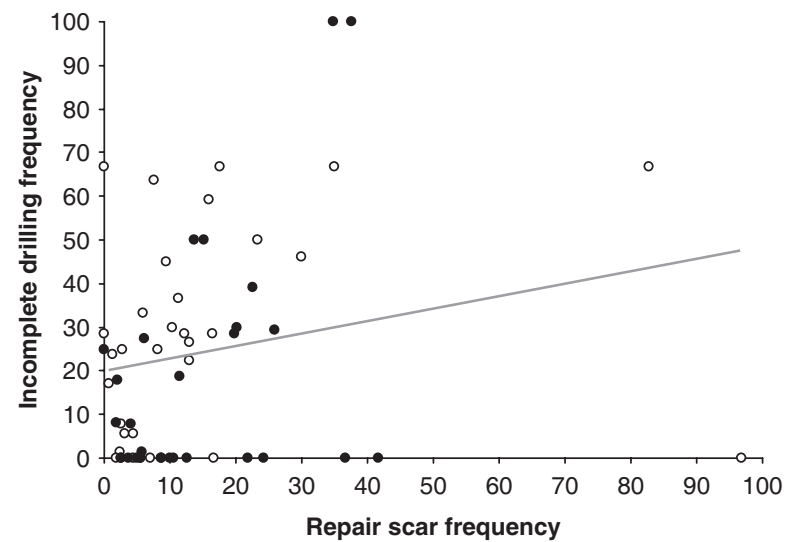

Figure 11. Plot showing the relationship between repair scar frequency and incomplete drilling for all the groups. Bivalves are represented by open circles and gastropods by solid circles.

Table 3. Contingency table for the $\chi^{2}$-test performed to evaluate the correlation between incomplete drilling and repair scar frequency for both bivalves and gastropods. Repair scars frequency categories are ' 0 to less than 8 ' and ' 8 and higher'. Drilling frequency categories are ' 0 to less than 10 ' and ' 10 and higher'.

\begin{tabular}{llr}
\hline & \multicolumn{2}{c}{$\begin{array}{c}\text { Incomplete drilling } \\
\text { frequency }\end{array}$} \\
\hline Repair scar frequency & \multicolumn{2}{c}{11} \\
& 11 & 20 \\
\hline
\end{tabular}

complete drill holes is negatively correlated with repair scars frequencies, whereas a positive relationship characterises frequencies of incomplete drill holes and repair scars. Before discussing the implications of these results in the context of our hypothesis, we first explore other ways in which the observed pattern might have been generated. It is essential to recognise that some factors (for instance, abundance of predator, taphonomic artefacts), although important in changing the frequencies separately, are most unlikely to generate such a pattern.

\section{Shell thickness}

Shell thickness is generally thought to be an important anti-predatory strategy (Vermeij 1983; Roopnarine and Beussink 1999; Dietl et al. 2000; Alexander and Dietl 2003; Leighton 2003; Kelley and Visaggi 2009) and differences in shell thickness of specimens found at different localities could generate a correlation similar to the observed patterns. For example, increasing shell thickness should lead to a decrease in drilling frequencies while incomplete drill hole frequencies should increase. Thicker shells should also be more resistant to

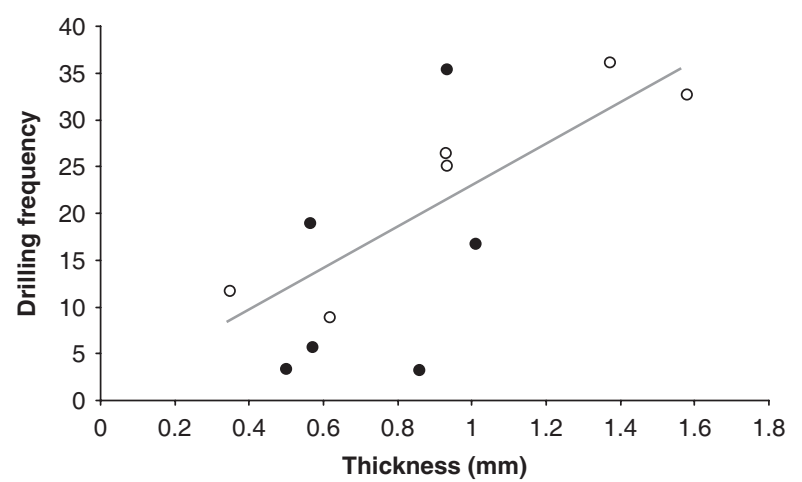

Figure 12. Plot showing the relationship between shell thickness and drilling frequency. Open circles represent bivalves and solid circles represent gastropods.

durophagous predation and this should lead to an increase in the incidence of unsuccessful attacks (repair scars). Hence, it is possible that varying thickness could produce a negative correlation between repair scar and drilling frequency, and a positive correlation between repair scar and incomplete drill hole frequency.

However, in our samples, we found no significant trends in complete drill hole, incomplete drill hole and repair scar frequencies with thickness and so it is quite unlikely that this hypothesis is true. In fact, the trends we found were opposite to those predicted by the 'shell thickness' scenario (Figures 12-14): the frequency of complete drill holes increased, of incomplete drill holes and repair scars decreased with increasing shell thickness.

\section{Prey selectivity}

The taxonomic compositions of localities used in this study differ. Assuming that predators vary in their preferences, if prey taxa preferred by a drilling predator were found at one locality but only less preferred prey

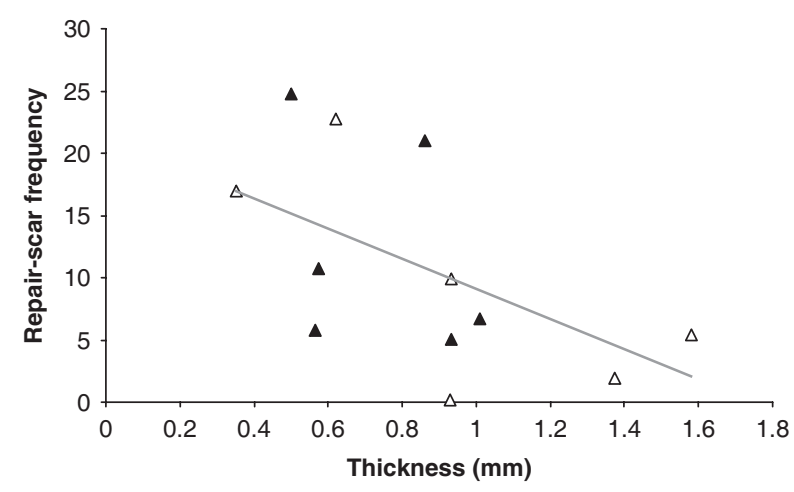

Figure 13. Plot showing the relationship between shell thickness and repair scar frequency. Open triangles represent bivalves and solid triangles represent gastropods. 


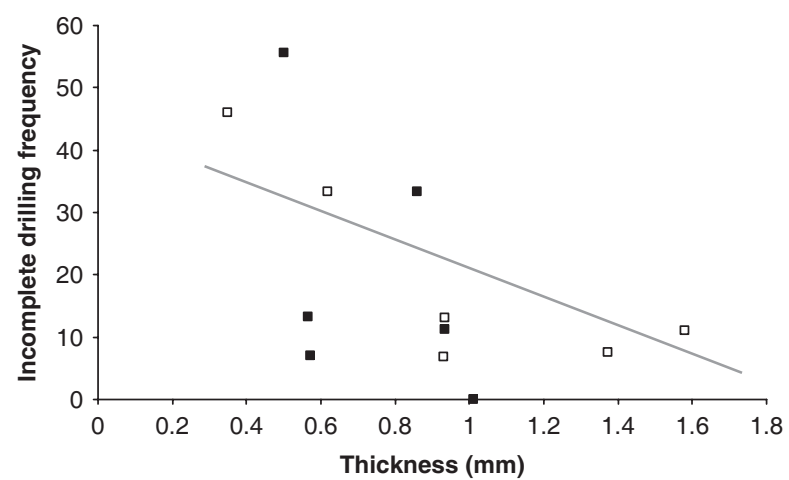

Figure 14. Plot showing the relationship between shell thickness and incomplete drilling. Open squares represent bivalves and solid squares represent gastropods.

were found at another, differences in drilling frequencies might result regardless of secondary predators. Similarly, if prey preferred by drilling predators rank low on a durophage's menu, a negative correlation between drilling and durophagous predation intensity might result.

The above highly contrived scenarios are unlikely because taxa in our samples are generally known to be heavily preyed upon by both drilling and durophagous predators based on reports from other localities (Kitchell et al. 1981; Anderson et al. 1991; Roopnarine and Beussink 1999; Alexander and Dietl 2001), the number of taxa at any locality is relatively large and the same scenario would have to apply to all taxa, and, finally, neither of the scenarios would explain the pattern for incomplete drill holes. Nevertheless, to test this hypothesis further, we restricted our analysis to a single taxon, $N$. duplicata, found in three of the six localities. For this single taxon, the relationship between drilling frequencies, incomplete frequencies and repair scar frequencies is

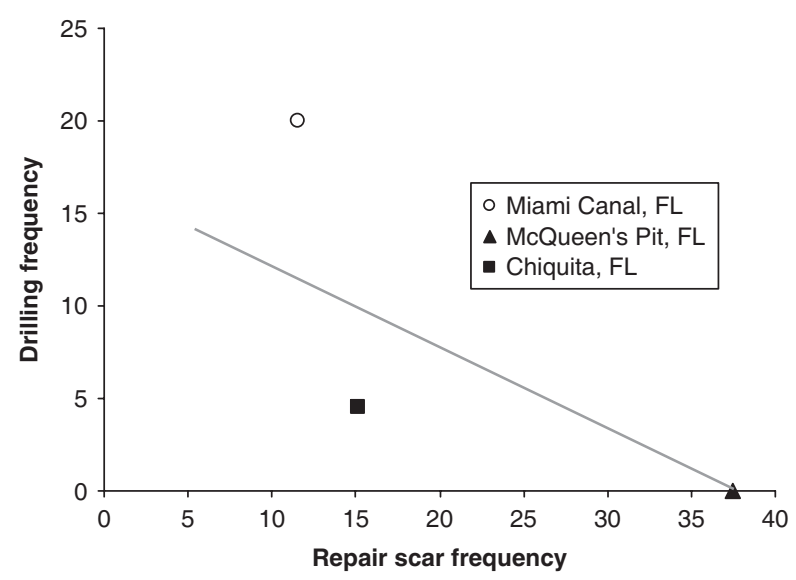

Figure 15. Plot showing the relationship between repair scar and drilling frequency for $N$. duplicata.

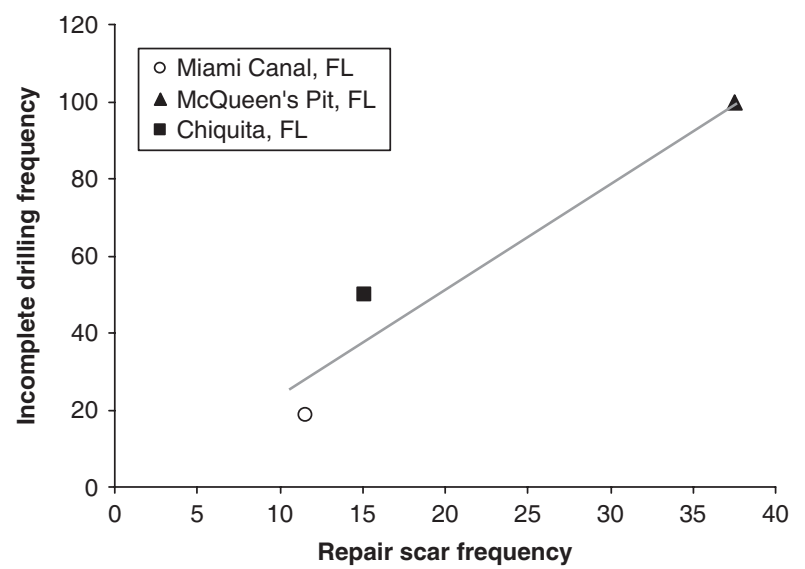

Figure 16. Plot showing the relationship between repair scar frequency and incomplete drilling for $N$. duplicata.

the same as that for all bivalves and gastropods (Figures 15 and 16).

\subsection{Repair scars as proxy of durophage activity}

The frequency of repair scars is a commonly used proxy for durophagous predator activities. For example, it has been used to evaluate the importance of predation as a selective agent (Vermeij 1982). Repair scars have also been used for durophagous predator activity varying with altitude (Shaffer 1978; Ballinger 1979), with latitude (Schall and Pianka 1980), between islands and mainland (Rand 1954) and between freshwater and marine habitats (Andrews 1935). It has also been used to explore the relationship between predation intensity and global diversity (Huntley and Kowalewski 2007). Nevertheless, because repair scars record failed attacks, their use as a measure of predator activity is not straightforward (Leighton 2001). Under some scenarios, increase in repair frequency can be a consequence of increasing prey resistance rather than predatory activity. Can the latter possibility be excluded in this study?

If repair frequency correlates with prey resistance rather than predator activity, one should be able to test this by examining repair frequencies as a function of some morphological trait, such as shell thickness that affect prey resistance. As our discussion of 'shell thickness' above (Figure 12) indicates, no significant trend exists between repair scar frequency and shell thickness. Moreover, if differences in repair scar frequencies were due to differences in prey resistance rather than to activities of secondary predators, a single prey species occurring across many localities should exhibit near constant frequencies of repair scars (assuming its resistance is constant across localities). As discussed above 'prey selectivity', $N$. duplicata shows a broad range of repair scar frequencies. 


\section{Latitude}

Predation intensity as a function of latitude has been the subject of much research (Dudley and Vermeij 1978; Vermeij et al. 1989; Allmon et al. 1990; Hansen and Kelley 1995; Kelley et al. 1997; Alexander and Dietl 2001; Hoffmeister and Kowalewski 2001; Kelley and Hansen 2007) and we must therefore consider the possibility that our repair scar and drilling frequency results might be a reflection of some unusual combination of latitudinal differences in predation activities rather than being causally connected.

The latitudinal effect for the observed patterns can be rejected because (1) the latitudinal range of our localities is narrow $\left(\sim 10^{\circ}\right)$; (2) there is no significant relationship between latitude and frequencies of drill holes and repair scars in our data (Figures 17 and 18) and (3) the variation in drill hole and repair scar frequencies among latitudinally more proximate localities is of the same magnitude as

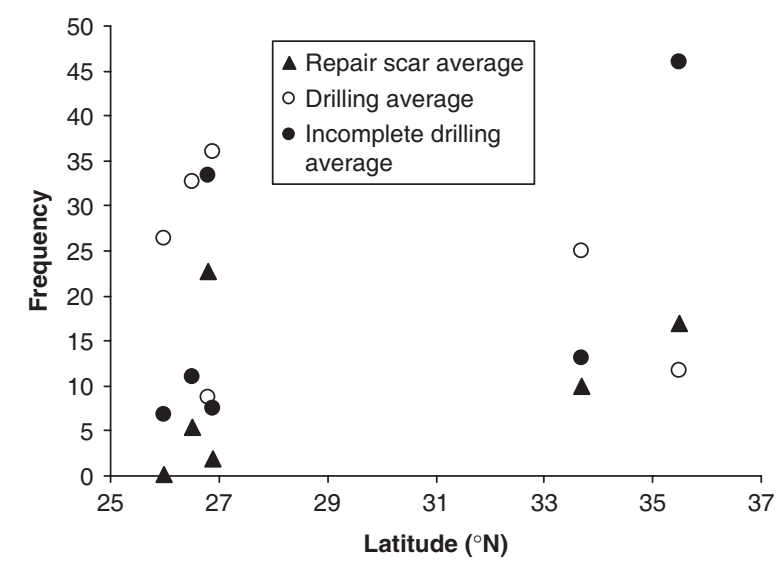

Figure 17. Plot showing the relationship between latitude of the localities and the average frequencies of drilling, repair scar and incomplete drilling of bivalves.

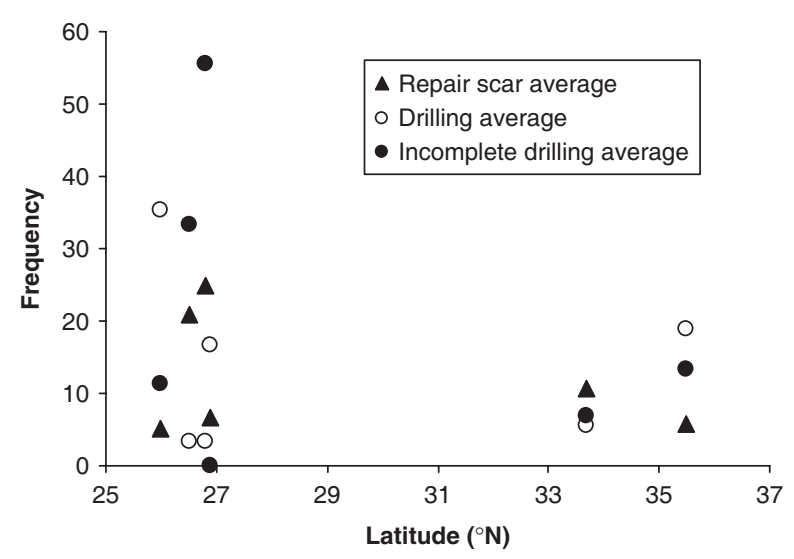

Figure 18. Plot showing the relationship between latitude of the localities and the average frequencies of drilling, repair scar and incomplete drilling of gastropods. variation for localities that are far apart rather than being more similar for latitudinally more proximate localities.

\section{Implications}

In reconstructing the record of drilling predation from fossils, paleontologists commonly rely on drilling frequency data. For example, some studies have used such data to compare predation intensities between different areas during the same (or nearly the same) temporal span (Jonkers 2000; Leighton 2001; Walker 2001; Baumiller and Bitner 2004), while others have used them to analyse temporal trends in predation intensity (Sohl 1969; Dudley and Vermeij 1978; Taylor et al. 1983; Allmon et al. 1990; Hagadorn and Boyajian 1997; Harper et al. 1998; Dietl and Alexander 2000; Leighton 2003; Amano 2006; Kelley and Hansen 2006). Although it is recognised that such frequencies may be influenced by extrinsic factors, in general they are interpreted in the context of predator and prey only. However, as a number of neontological studies illustrate, natural systems might be multi-tiered and include secondary predators, and that can have a significant impact on drilling frequencies. In those instances, interpreting changes in frequencies as due to changes in the relative performance of drilling predators and their prey would be inaccurate.

In this study, the presence of secondary predators was recognised from repair marks made by shell-crushing predators, but pre-ingestive breakage or crushing is only one of four methods of molluscivory, the others being whole-organism ingestion, insertion and extraction, and drilling (Vermeij 1987; Harper and Skelton 1993). Unfortunately, whole-organism ingestion, and insertion and extraction, although common, are unlikely to leave preservable evidence. As a consequence, the effect of these predators on drilling predation is likely to go unnoticed.

The complexities and outcomes of multi-tiered interactions prompt us to revisit concepts of co-evolution and escalation. The major difference between co-evolution and escalation is in the nature of selection (Vermeij 1994). Escalation is enemy-driven evolution where the role of prey (with exception of dangerous prey) is relatively unimportant in arms races between predator and prey. In co-evolution, prey are linked tightly to their predator and are thought to drive the predator's evolution. In the presence of secondary predators, the predictions of these two hypotheses differ. If escalation is acting, one would expect changes in traits (morphological or behavioural) of the predator (such as the drilling gastropod) to be a function of its predator's (secondary predator) activity, whereas under a co-evolutionary scenario, evolutionary change in the predator would be primarily in response to its prey. In the long run, if escalation is the prevalent mode of change, changes in drilling and incomplete drilling 
frequency would be a function of activity of secondary predators. However, in nature the evolutionary mode is likely to be a combination of the two. For instance, we might expect to see changes in behavioural traits such as drilling rate, feeding rate or stereotypy that would give some evolutionary advantage to the driller against the mortality risk imposed by the predator. These traits, however, would also be affected by the response of the prey. In order to evaluate the nature of evolutionary change in multi-tiered predator-prey systems, a proper assessment of risk through time is necessary. In cases such as represented by this study, the risk for a drilling predator through time is likely to be dependent on the diversity (and success) of durophagous predators. It has been recognised that the evolution and diversification of durophagous predators through the Phanerozoic had profound effects upon the structure of benthic communities (Bottjer 1985; Bambach 1993) and upon the evolution of shelled invertebrates. How much it affected the evolution of the behaviour of drilling predators is yet to be evaluated. A slightly different approach would be to evaluate the effect of disappearance of a durophagous group on drilling predation.

The impact of secondary predators may also be recognised in the Recent by comparing systems in which activities of durophages differ. For example, whereas durophagous predation remains strong in the Arctic (Dayton 1990), it has been virtually absent from Antarctica from Eocene onwards (Aronson and Blake 2001). One prediction of this pattern based on the results of this study is that higher drilling frequencies and lower incomplete drilling frequencies should characterise Antarctic assemblages compared to Arctic assemblages.

\section{Conclusions}

In reconstructing the record of drilling predation from fossils, paleontologists commonly rely on data on drilling frequencies. Temporal patterns in drilling frequencies have been used as evidence of arms races. Using PlioPleistocene fossil assemblages, we demonstrated that there is a strong negative correlation between repair scar and drilling frequencies which is consistent with our hypothesis of a deterrent effect of secondary predator on drilling predation. The observed positive correlation between repair scar and incomplete drilling frequencies also supports our hypothesis. Although, drilling frequency has been used to explore co-evolution and escalation, it has generally been analysed in the context of a two-taxon system. Modern neontological literature demonstrates that often the effect of threat from an enemy modifies the behavioural response of a predator. Since frequency of complete and incomplete drill holes often depends on the driller's behavioural response to ambient threat, it could be used as an important proxy of behavioural response in tracking the mode of 'enemy-driven evolutionary change' or escalation through time.

\section{Acknowledgements}

This project was funded in part by grants from the Conchologists of America Research and Geological Society of America and the National Science Foundation (USA). We would like to thank Sarah Groat for her invaluable help with data collection. The senior author is very thankful for the comments from G.A. Janevski, D.J. Miller and G. Vermeij on earlier drafts of this manuscript. We thank P. Kelley and M. Kowalewski and an anonymous reviewer for constructive comments.

\section{References}

Abrams PA, Menge BA, Mittlebach GG, Spiller D, Yodzis P. 1996. The role of indirect effects in food webs. In: Polis G, Winemiller K, editors. Food webs: dynamics and structure. New York (NY): Chapman and Hall. p. 371-395.

Alexander RR, Dietl GP. 2001. Shell repair frequencies in New Jersey bivalves: a recent baseline for tests of escalation with Tertiary, MidAtlantic congeners. Palaios. 16:354-371.

Alexander RR, Dietl GP. 2003. The fossil record of shell-breaking predation on marine bivalves and gastropods. In: Kelley $\mathrm{PH}$, Kowalewski M, Hansen TA, editors. Predator-prey interactions in the fossil record: topics in geobiology series 20. New York (NY): Plenum Press/Kluwer. p. 141-170.

Allmon WD, Nieh JC, Norris RD. 1990. Drilling and peeling of Turritelline gastropods since the Late Cretaceous. Palaeontology. 33:595-611.

Amano K. 2006. Temporal pattern of naticid predation on Glycymeris yessoensis (sowerby) during the Late Cenozoic in Japan. Palaios. 21:369-375.

Anderson LC, Geary DH, Nehm RH, Allmon WD. 1991. A comparative study of naticid gastropod predation on Varicorbula caloosae and Chione cancella, Plio-Pleistocene of Florida, USA. Palaeogeogr Palaeoclimatol Palaeoecol. 85:29-46.

Andrews EA. 1935. Shell repair by the snail, Neritina. J Exp Zool. 70:75-107.

Aronson RB, Blake DB. 2001. Global climate change and the origin of modern benthic communities in Antarctica. Am Zool. 41:27-39.

Ausich WI, Gurrola RA. 1979. Two boring organisms in a Lower Mississippian community of southern Indiana. J Paleontol. $53: 335-344$.

Ballinger RE. 1979. Intraspecific variation in demography and life history of the lizard, Sceloporus jarrovi, along an altitudinal gradient in southeastern Arizona. Ecology. 60:901-909.

Bambach R. 1993. Seafood through time: changes in biomass, energetics, and productivity in the marine ecosystem. Paleobiology. 19:372-397.

Baumiller TK, Bitner MA. 2004. A case of intense predatory drilling of brachiopods from the Middle Miocene of southeastern Poland. Palaeogeogr Palaeoclimatol Palaeoecol. 214:85-95.

Berg CJ Jr, Nishenko S. 1975. Stereotypy of predatory boring behavior of Pleistocene naticid gastropods. Paleobiology. 1:258-260.

Bottjer D. 1985. Bivalve paleoecology. In: Bottjer DJ, Hickman CS, Ward PD, editors. Mollusks: notes for a short course, University of Tennessee, Department of Geological Sciences Studies in Geology, 13:112-137.

Chattopadhyay D, Baumiller TK. 2007. Drilling under threat: an experimental assessment of the drilling behavior of Nucella lamellosa in the presence of a predator. J Exp Mar Biol Ecol. 352:257-266.

Colbath SL. 1985. Gastropod predation and depositional environments of two Molluscan communities from the Miocene Astoria Formation at Beverly Beach State Park, Oregon. J Paleontol. 59:849-869.

Conway Morris S, Bengtson S. 1998. Cambrian predators: possible evidence from boreholes. J Paleontol. 68:1-23. 
Dayton PK. 1990. Polar benthos. In: Smith WO Jr, editor. Polar oceanography, Part B: chemistry, biology, and geology. San Diego (CA): Academic Press. p. 631-685.

Deline B, Baumiller T, Kaplan P, Kowalewski M, Hoffmeister A. 2003. Edge-drilling on the brachiopod Perditocardinia cf. P. dubia from the Mississippian of Missouri (USA). Palaeogeogr Palaeoclimatol Palaeoecol. 201:211-219.

Dietl GP, Alexander RR. 1998. Shell repair frequencies in whelk and moon snails from Delaware and southern New Jersey. Malacologia. 39:151-165.

Dietl GP, Alexander RR. 2000. Post-Miocene shift in stereotypic Naticid predation on confamilial prey from the Mid-Atlantic shelf: coevolution with dangerous prey. Palios. 4:414-429.

Dietl GP, Kelley PH. 2004. Emergent effects of multiple predators on prey in the fossil record. Geol Soc Am Abstracts Programs. 36:480.

Dietl GP, Alexander RR, Bien W. 2000. Escalation in Late Cretaceousearly Paleocene oysters (Gryphaeidae) from the Atlantic Coastal Plain. Paleobiology. 26:215-237.

Dill LM. 1987. Animal decision making and its ecological consequences: the future of aquatic ecology and behavior. C J Zool. 65:803-811.

Dudley EC, Vermeij GJ. 1978. Predation in time and space; drilling in the gastropod Turritella. Paleobiology. 4:436-441.

Hagadorn J, Boyajian GE. 1997. Subtle changes in mature predator-prey systems; an example from Neogene Turritella (Gastropoda). Palios. 4:372-379.

Hansen TA, Kelley PH. 1995. Spatial variation of naticid gastropod predation in the Eocene of North America. Palios. 10:268-278.

Harper EM. 2006. Dissecting post-Palaeozoic arms races. Palaeogeogr Palaeoclimatol Palaeoecol. 232:322-343.

Harper EM, Skelton PW. 1993. The Mesozoic marine revolution and epifaunal bivalves. Scripta Geologica. Special issue 2:127-153.

Harper EM, Forsythe GTW, Palmer T. 1998. Taphonomy and the Mesozoic marine revolution: preservation state masks the importance of boring predators. Palios. 13:352-360.

Hoffman A, Martinell J. 1984. Prey selection by gastropods in the Pliocene of Emporda (Northeast Spain). Neues Jahrbuch für Geologie und Paläontologie Monatshefte. 7:393-399.

Hoffmeister AP, Kowalewski M. 2001. Spatial and environmental variation in the fossil record of drilling predation: a case study from the Miocene of central Europe. Palios. 16:566-579.

Huntley JW, Kowalewski M. 2007. Strong coupling of predation intensity and diversity in the Phanerozoic fossil record. Proc Natl Acad Sci. 104:15006-15010.

Jablonski D, Sepkoski JJ Jr. 1996. Paleobiology, community ecology, and scales of ecological pattern. Ecology. 77:1367-1378.

Jonkers HA. 2000. Gastropod predation patterns in Pliocene and Recent pectinid bivalves from Antarctica and New Zealand. N Zeal J Geol Geophys. 43:247-254.

Kabat AR, Kohn AJ. 1986. Predation on Early Pleistocene naticid gastropods in Fiji. Palaeogeogr Palaeoclimatol Palaeoecol. 53:255-269.

Kelley PH, Hansen TA. 1993. Evolution of Naticid predator-prey system: an evaluation of the hypothesis of escalation. Palaios. $8: 358-375$.

Kelley PH, Hansen TA. 2001. The role of ecological interactions in the evolution of naticid gastropods and their molluscan prey. In: Allmon W, David J, Bottjer DJ, editors. Evolutionary paleoecology: the ecological context of macroevolutionary change. New York (NY): Columbia University Press. p. 149-170.

Kelley PH, Hansen TA. 2003. The fossil record of drilling predation on bivalves and gastropods. In: Kelley PH, Kowalewski M, Hansen TA, editors. Predator-prey interactions in the fossil record: topics in geobiology series 20. New York (NY): Plenum Press/Kluwer. p. $113-133$.

Kelley PH, Hansen TA. 2006. Comparisons of class- and lower taxonlevel patterns in naticid gastropod predation, Cretaceous to Pleistocene of the US coastal plain. Palaeogeogr Palaeoclimatol Palaeoecol. 236:302-320.

Kelley PH, Hansen TA. 2007. Latitudinal patterns in naticid gastropod predation along the east coast of the United States: a modern baseline for interpreting temporal patterns in the fossil record. In: Bromley RG, Buatois LA, Mángano MG, Genise JF, Melchor RN, editors.
Sediment-organism interactions: a multifaceted ichnology. Tulsa (OK): SEPM Special Publications 88. p. 284-299.

Kelley PH, Visaggi C. 2009. Latitudinal patterns in predation by shelldrilling gastropods: are differences in preservation potential responsible? Geol Soc Am Abstracts Programs. 41:706.

Kelley PH, Thomann C, Hansen TA, Aronson R, Blake D. 1997. A world apart but not so different: predation by naticid gastropods in Antarctica and the US Gulf Coast during Eocene. Geol Soc Am Abstract Programs. 29:A107.

Kitchell JA, Boggs CH, Kitchell JF, Rice JA. 1981. Prey selection by naticid gastropods: experimental tests and application to the fossil record. Paleobiology. 7:33-552.

Kowalewski M. 2002. The fossil record of predation: an overview of analytical methods. Paleontol Soc Spec Papers 8:3-42.

Kowalewski M. 2004. Drill holes produced by the predatory gastropod Nucella lamellosa (Muricidae): paleobiological and ecological implications. J Moll Stud. 70:359-370.

Kowalewski M, Dulai A, Fuersich FT. 1998. A fossil record full of holes: the Phanerozoic history of drilling predation. Geology. 26:1091-1094.

Leighton L. 2001. New example of Devonian predatory boreholes and the influence of brachiopod spines on predator success. Palaeogeogr Palaeoclimatol Palaeoecol. 165:53-69.

Leighton LR. 2002. Inferring predation intensity in the marine fossil record. Paleobiology. 28:328-342.

Leighton LR. 2003. Morphological response of prey to drilling predation in the Middle Devonian. Palaeogeogr Palaeoclimatol Palaeoecol. 201:221-234.

Lima SL. 1988a. Nonlethal effects in the ecology of predator-prey interactions - what are the ecological effects of prey interactions what are the ecological effects of anti-predator decision making? BioScience. 48:25-34.

Lima SL. 1988b. Stress and decision making under the risk of predation: recent developments from behavioral, reproductive, and ecological perspectives. Adv Stud Behav. 27:215-290.

Lima SL, Dill LM. 1990. Behavioral decisions made under the risk of predation: a review and prospectus. C J Zool. 68:619-640.

Marko PB, Palmer AR. 1991. Responses of a rocky shore gastropod to the effluents of predatory and non-predatory crabs: avoidance and attraction. Biol Bull. 181:363-370.

Moody RM, Aronson RB. 2007. Trophic heterogeneity in salt marshes of the northern Gulf of Mexico. Mar Ecol Progr Ser. 331:49-65.

Palmer AR. 1990. Effect of crab effluent and scent of damaged conspecifics on feeding, growth, and shell morphology of the Atlantic dogwhelk Nucella lapillus (L.). Hydrobiologia. 193:155-182.

Rand AS. 1954. Variation and predation pressure in an island and a mainland population of lizards. Copeia. 1954:260-262.

Roopnarine PD, Beussink A. 1999. Extinction and naticid predation of the bivalve Chione Von Muhlfeld in the Late Neogene of Florida. Palaeontologica Electronica. V. 2, art. 1: 24 p., $719 \mathrm{kB}$.

Schall JJ, Pianka ER. 1980. Evolution of escape behavior diversity. Am Nat. 115:551-566.

Shaffer HB. 1978. Relative predation pressure on salamanders (Caudata: Plethodontidae) along an altitudinal transect in Guatemala. Copeia. 1978:268-272.

Signor PW III, Brett CE. 1984. The Mid-Paleozoic precursor to the Mesozoic marine revolution. Paleobiology. 10:229-245.

Sih A, Crowley P, Mcpeek M, Petranka J, Strohmeier K. 1985. Predation, competition, and prey communities: a review of field experiments. Ann Rev Ecol Syst. 16:269-311.

Sih A, Englund G, Wooster D. 1998. Emergent impacts of multiple predators on prey. Trends Ecol Evol. 13:350-355.

Sohl NF. 1969. The fossil record of shell boring by snails. Am Zool. 9:725-734.

Stanley SM. 1974. What has happened to the articulate brachiopods? Geol Soc Am Abstracts Programs. 8:966-967.

Stanley SM. 1976. Fossil data and the Precambrian-Cambrian evolutionary transition. Am J Sci. 276:56-76.

Stanley SM. 1979. Macroevolution: pattern and process. San Francisco (CA): WH Freeman and Company. 332 pp. 
Stanton RJ Jr, Nelson PC. 1980. Reconstruction of the trophic web in paleontology: community structure in the Stone City Formation (middle Eocene, Texas). J Paleontol. 54:118-135.

Taylor JD. 1970. Feeding habits of predatory gastropods in a Tertiary (Eocene) molluscan assemblage from the Paris basin. Palaeontology. 23:254-260.

Taylor JD, Cleevly RJ, Morris NJ. 1983. Predatory gastropods and their activities in the Blackdown Greensand (Albian) England. Palaeontology. 26:521-553.

Trussell GC, Patrick EJ, Bertness MD. 2003. Trait-mediated effects in rocky intertidal food chains: Predator risk cues alter prey feeding rates. Ecology. 84:629-640.

Tull DS, Bohning-Gaese K. 1993. Patterns of drilling predation on gastropods of the Family Turritellidae in the Gulf of California. Paleobiology. 19:476-486.

Turner AM. 1996. Freshwater snails alter habitat use in response to predation. Anim Behav. 51:747-756.

Turner AM. 1997. Contrasting short-term and long-term effects of predation risk on consumer habitat use and resources. Behav Ecol. $8: 120-125$.

Turner AM, Mittlebach GG. 1990. Predation avoidance and community structure: interactions among piscivores, planktivores, and plankton. Ecology. 71:2241-2254.

Turner AM, Fetterolf SA, Bernot RJ. 1999. Predator identity and consumer behavior: differential effects of fish and crayfish on the habitat use of a freshwater snail. Oecologia. 118:242-247.

Turner AM, Bernot RJ, Boes CM. 2000. Chemical cues modify species interactions: the ecological consequences of predator avoidance by freshwater snails. Oikos. 88:148-158.

Vermeij GJ. 1982. Unsuccessful predation and evolution. Am Nat. 120:701-720
Vermeij GJ. 1983. Traces and trends of predation, with special reference to bivalved animals. Palaeontology. 26:455-465.

Vermeij GJ. 1987. Evolution and escalation: an ecological history of life. Princeton (NJ): Princeton University Press. 527 pp.

Vermeij GJ. 1994. The evolutionary interaction among species: selection, escalation, and coevolution. Ann Rev Ecol Syst. 25:219-236.

Vermeij GJ, Dudley EC. 1982. Shell repair and drilling in some gastropods from the Ripley Formation (Upper Cretaceous) of Southeastern USA. Cret Res. 3:397-403.

Vermeij GJ, Zipser E, Dudley EC. 1980. Predation in time and space: peeling and drilling in Terebrid gastropods. Paleobiology. 6:352-364.

Vermeij GJ, Schindel DE, Zipser E. 1981. Predation through geological time: evidence from gastropod shell repair. Science. 214:1024-1026.

Vermeij GJ, Zipser E, Dudley EC. 1989. Successful and unsuccessful drilling predation in Recent pelecypods. Veliger. 32:266-273.

Walker SE. 2001. Paleoecology of gastropods preserved in turbiditic slope deposits from the Upper Pliocene of Ecuador. Palaeogeogr Palaeoclimatol Palaeoecol. 166:141-163.

Werner EE, Anholt BR. 1993. Ecological consequences of the trade-off between growth and mortality rates mediated by foraging activity. Am Nat. 142:242-272.

Wilbur HM, Fauth JE. 1990. Experimental aquatic food webs: interactions between two predators and two prey. Am Nat. 135:176-204.

Wooton JT. 1994. Predicting direct and indirect effects: an integrated approach using experiments and path analysis. Ecology. $75: 151-165$.

Zlotnik M. 2001. Size-related changes in predatory behaviour of naticid gastropods from Middle Miocene Korytnica Clays, Poland. Acta Palaeontol Polonica. 46:87-97. 